\title{
Exploring childhood, criminal responsibility and the evolving capacities of the child: the age of criminal responsibility in England and Wales
}

\author{
RAYMOND ARTHUR*
}

Northumbria University

\begin{abstract}
Currently in England and Wales the law considers that all children below 10 years of age are exempt from criminal liability for their actions as such children are morally not responsible and lacking blameworthiness. This approach to young people in conflict with the law misrepresents the evidence regarding young people who offend and encourages highly contestable judgements about individuality, identity and welfare. I will argue that children have a right to respect for their evolving capacities and that respecting this right would help to redirect the criminal justice system towards a normative framework better equipped to accommodate the realities of childhood and in which the child's experience of vulnerability and powerlessness is embedded throughout.
\end{abstract}

\section{Introduction}

$\mathrm{I}^{\mathrm{n}}$ n England and Wales the age of criminal responsibility is set at 10 years. The current law therefore assumes all children are sufficiently mature at the age of 10 to accept criminal responsibility for their behaviour. This means that normative criteria, such as the physiological and psychological development of the individual child, are not being used to identify the divide between childhood and adulthood. Instead, the low age of criminal responsibility misrepresents the evidence we have regarding young people who offend and their evolving capacities. Children are still in the process of maturing at this stage of life and may not yet be developed enough to understand the wrongfulness of what they do. Children and young people are less mature than adults in terms of their judgement and sensation-seeking and experience difficulties in weighing and comparing consequences when making decisions and contemplating the meaning of long-range consequences. These cognitive difficulties also have implications for a young person's ability to be a competent defendant in an adversarial atmosphere. Young defendants who may not understand the consequence of their offending, including those with impaired mental capacity, are exposed to the full rigours of the criminal justice system unless their decision-making capacities are impaired, for example, by a mental illness which is attributable to a condition falling within the M'Nagthen rules, or they are substantially intellectually impaired.

This approach to young people in conflict with the law effectively constructs such children as non-children who do not deserve to remain children. Consequently, the rights of the offender as a child, in particular, marginalised and socially excluded children,

* Reader in Law, Faculty of Business and Law. 
become invisible and ignored. This article will argue that children have a right to respect for their evolving capacities and that respecting this right would redirect the criminal justice system towards a normative framework better equipped to accommodate the realities of childhood; one which contains a clear foregrounding of the child's experiences and the reality of their daily lives and in which the child's experience of vulnerability and powerlessness is embedded throughout. If such a focus on children's rights were applied to young people in conflict with the law, it would ensure that young people who are not sufficiently mature and competent to understand the process of a trial in a criminal court, including the youth court, could not be held criminally culpable for their behaviour. Criminal liability could only be imposed upon children who had sufficient mental capacity, competence and maturity to understand the nature of their conduct and exercise volition over their behaviour.

\section{Childhood}

Ferguson has argued that any debate over the value of children's rights both begins and ends with the social construction of childhood. ${ }^{1}$ Childhood is a contested terrain which suggests the physical growth of the child to full maturity, mirrored by intellectual, psychological, social and moral development. ${ }^{2}$ Aries noted that in medieval society the idea of childhood did not exist' and that various languages did not even have words to describe childhood. ${ }^{3}$ Aries argued that it was not until the mid-eighteenth century that the modern concept of childhood emerged, with the child occupying a central place in the family. For the Romantics, the concept of childhood became synonymous with a concept of 'original innocence' derived from Rousseau. Rousseau, in Social Contract of 1762, considered that childhood was a period of innocence and mutability. ${ }^{4}$ In particular, he stressed the natural goodness of children and evoked sentiments that children were deserving of protection and education rather than punishment. For Rousseau, the innocent child is recognisable through encouragement, assistance, support and facilitation. Similarly Locke, in Some Thoughts Concerning Education $(1693)^{5}$ and An Essay on Human Understanding (1700), ${ }^{6}$ believed that, whatever children are, they are not partially formed adults as there are incontrovertible cognitive and developmental differences between adults and children. Locke believed that children did not possess inbuilt categories of understanding or a general facility to reason. Locke assumed that through natural development the child's dependency, incompetence and irrationality give way to adult independence, competency and the ability to reason and to act responsibly. ${ }^{7}$ These views sowed the seeds of the belief that children are everybody's concern and that they constitute an investment in the future in terms of the reproduction of social order.

From the middle of the nineteenth century the concept of childhood developed together with ideas of responsibility for children's moral and social development. Out of this developed notions of parental responsibility and the general collective interest of the

1 Lucinda Ferguson, 'Not Merely Rights for Children but Children's Rights: The Theory Gap and the Assumptions of the Importance of Children's Rights' (2013) 21 International Journal of Children's Rights $177,179$.

2 Deena Haydon and Phil Scraton, “'Condemn a Little More, Understand a Little Less”: The Political Context and Rights Implications of the Domestic and European Rulings in the Venable-Thompson case' (2000) 27(3) Journal of Law and Society 416.

3 Philippe Aries, Centuries of Childhood (Penguin 1962).

4 Jean-Jacques Rousseau, Social Contract (Penguin 1968)

5 John Locke, Some Thoughts Concerning Education (A \& J Churchill 1693)

6 John Locke, An Essay on Human Understanding (Beecroft 1700)

7 Also Allison James, Chris Jenks and Alan Prout, Theorizing Childhood (Polity 1998) 10-12. 
state for the well-being of children as a future generation. ${ }^{8}$ Such realities were bolstered by law. Compulsory education began to develop during the 1870 s and cruelty to children became a criminal offence with the passing of the Prevention of Cruelty to Children Act 1899. The 1899 Act aimed to deter the mistreatment of children and made it an offence for a person over the age of 16 years to 'assault, ill-treat, neglect or abandon any child for whom he has responsibility'. These modern constructions of childhood dictate empowering children through seeing them as deserving of some respect and privileging of children's special interests through acknowledging the aspirations of rights for children.

Arneil argues that children's rights theorists have very good reason for advocating rights for children. If you want to take children's needs and interests seriously, and make claims on their behalf that will compete with any other moral claims, it is necessary to make such claims in the language of rights. It is clear that any non-rights moral claim simply does not carry the same weight in contemporary moral or political debate. ${ }^{9}$ Similarly, Archard reasons that '[p]erhaps it is a fundamental mistake legally to give children that to which they are not morally entitled'; nevertheless, giving children legal rights will make a huge difference to how we think about them. ${ }^{10}$ For Ferguson, rights talk is beneficial because it empowers children in the sense of ensuring their equal respect and it enfranchises them by enabling their unique narratives and perspectives to be shared. However, Brighouse warns that children's rights talk could 'systematically mislead people into neglecting the facts of children's vulnerability, dependence, and inabilities'. ${ }^{11}$ Similarly, O'Neill argues that children's fundamental rights are best grounded by embedding them in a wider account of fundamental obligations, which can also be used to justify positive rights and obligations. ${ }^{12}$ O'Neill examined the legal and moral principles behind children's rights. She argued that children should be protected and nurtured because of their special vulnerabilities and thus should not have full rights. Huntington supports this view, arguing that children do not have full autonomy and, therefore, rights as a mechanism for promotion of their welfare or access to citizenship are ineffective and inappropriate. ${ }^{13}$ Huntington argues that a rights-based model of child welfare does not protect the interests of children as it privileges autonomy over assistance and obscures the important role of poverty in the lives of children suffering disadvantage; it perpetuates an adversarial approach to decision-making and consequently fosters conflict, rather than collaboration, between the state and families. Huntington therefore recommends 'shifting rights to the background'14 echoing O'Neill's view that a child's 'main remedy is to grow up'. ${ }^{15}$ However, this proposed remedy is of little use to young people involved in the criminal justice system. There is considerable evidence to confirm that the criminalisation of children is associated with higher levels of offending in adulthood. Significantly, this effect has been demonstrated across different jurisdictions, including those that adopt more or less punitive approaches to youth-

8 Michael Wyness, Childhood and Society (Palgrave 2006); Robert Dingwall, John Eekelaar and Topsy Murray, The Protection of Children: State Intervention and Family Life 2nd edn (Blackwell 1995) 220.

9 Barbara Arneil, 'Becoming Versus Being: A Critical Analysis of the Child in Liberal Theory' in David Archard and Colin M Macleod, The Moral and Political Status of Children (OUP 2002) 86.

10 David Archard, Children: Rights and Childhood 2nd edn (Routledge 2004$) 57$.

11 Harry Brighouse, 'What Rights (if Any) Do Children Have?' in Archard and Macleod (n 9) 35.

12 Onora O’Neill, 'Children's Rights and Children's Lives' (1988) 98 Ethics 445; see also, Onora O’Neill, 'Children's Rights and Children's Lives' (1992) 6 International Journal of Law and the Family 24.

13 Claire Huntington, 'Rights Myopia in Child Welfare' (2006) 53 UCLA Law Review 637.

14 Ibid 642.

15 O’Neill (n 12). 
offending. ${ }^{16}$ Contact with the youth justice system reduces the likelihood that children will complete school and obtain educational qualifications and, consequently, impacts directly on the chances of future employment. ${ }^{17}$

In this article I will argue that in the context of the youth justice system in general, and the age of criminal responsibility in particular, emphasising an approach which recognises that the child has rights helps to ensure a clear foregrounding of the child's experiences and an invitation to empathise with the child's feelings. Acknowledging the child's right to respect for their evolving capacity holds significant potential to address many of the profound theoretical and practical shortcomings of the youth justice system. ${ }^{18}$ The expressive values of rights should not be discounted as mere semantics, rights matter to children because the language of children's rights may be regarded as a vital tool in defending the intrinsic importance of children and articulating what it is about children that gives them such value. ${ }^{19}$ Choudhry and Fenwick contend that thinking in terms of rights makes it more likely that we consider all the relevant interests at stake because of the explicit articulation such an analysis requires. ${ }^{20}$ Considering the issue in broader terms, Freeman reasons that: ' $[t]$ he language of rights can make visible what has for too long been suppressed. It can lead to different and new stories being heard in public. ${ }^{21}$ The suggestion is that, even if outcomes remained unchanged, it would be better for children to be seen through the lens of rights. ${ }^{22}$ As Ferguson notes:

The statement that a child has a particular right is both an expression of an existing social norm that recognises the importance of the content of that legal right to the child, as well as a means of changing social norms to be more reflective of that importance. ${ }^{23}$

The relevance and application of a child's rights-based approach in the context of children's criminal capacity cannot be underestimated as this approach acknowledges children's inherent vulnerability and immaturity and their lack of capacity and agency to make decisions in their own best interests. Woodhouse has characterised such an approach as an environmentalist model that focuses on the ecology of the child rather than the child as an isolated individual. ${ }^{24}$ Such an 'environmentalist/rights' approach would better serve the twin goals of the youth justice system to prevent offending by children and young

16 Tim Bateman, Children in Conflict with the Law: An Overview of Trends and Developments - 2010/2011 (National Association for Youth Justice 2012); David Huizinga, Karl Schumann, Beate Ehret and Amanda Elliott, The Effect of Juvenile Justice System Processing on Subsequent Delinquent and Criminal Behavior: A Cross-National Study (US Department of Justice 2003); Leslie McAra and Susan McVie, 'Youth Justice?: The Impact of System Contact on Patterns of Desistance from Offending' (2007) 4(3) European Journal of Criminology 315.

17 Jon G Bernburg and Marvin D Krohn, 'Labelling Life Chances and Adult Crime: The Direct and Indirect Effects of Official Intervention in Adolescence on Crime in Early Adulthood' (2003) 41(4) Criminology 1287.

18 See Kathryn Hollingsworth, 'Theorising Children's Rights in the Youth Justice System: The Significance of Autonomy and Foundational Rights' (2013) 76(6) Modern Law Review 1049; Raymond Arthur, 'Recognising Children's Citizenship in the Youth Justice System’ (2015) 37(1) Journal of Social Welfare and Family Law 21.

19 Tom D Campbell, 'The Rights of the Minor: As Person, as Child, as Juvenile, as Future Adult' (1992) 6 International Journal of Law and the Family 1.

20 Shazia Choudhry and Helen Fenwick, 'Taking the Rights of Parents and Children Seriously: Confronting the Welfare Principle under the Human Rights Act' (2005) 25 Oxford Journal of Legal Studies 454, 468-69.

21 Michael D Freeman, 'Why it Remains Important to Take Children's Rights Seriously' (2007) 15 International Journal of Children's Rights 6.

22 Ibid 7.

23 Ferguson (n 1) 183.

24 Barbara B Woodhouse, 'Reframing the Debate about the Socialization of Child Welfare: An Environmental Paradigm’ 2004 University of Chicago Legal Forum 85. 
people 25 and to have regard to the welfare of the child. ${ }^{26}$ This focus on children as rightsholders would avoid conflict between the competing rights of young people, parents, victims and the state and instead create a rhetoric which focuses more on adult responsibility and children's needs and the broader issues affecting the young person.

\section{Children's rights approach to the 'age of criminal responsibility'}

Babic is critical of any approach which offers a 'fairly undifferentiated understanding of children and childhood' and which fails to recognise that a child does not simply 'turn into an adult all of a sudden but needs to go through processes of development and growth till they reach adulthood'. ${ }^{27}$ Children of 10 years are not adults and the more a young person is involved with crime, the greater the gap with adults tends to be. Yet, once they are 10 years of age, they can be subject to an adversarial system, modelled closely on a criminal justice system designed for convicting and punishing adults, a system that prioritises the finding of guilt or innocence and sentencing for a particular offence. The low age of criminal responsibility in England and Wales reflects a simplistic functionalist perspective which focuses its attention on a policy of containment through the morality of blaming young people's behaviour as a product of personal pathology. This construction of childhood is wedded to a punitive model which focuses on the offence alone at the expense of considering the connections between the child and their wider social situation. This approach ignores the socio-economic and cultural contexts of young people's lives and fails to respect the child's present and future rational autonomy and capacity. It ignores the evidence that the child's inexperience and under-developed powers of self-control and reasoning make them prone to acting in ways they cannot help, understand or intend. Instead, children who are involved in offending behaviour are reconstructed as non-children and consequently are denied the right to respect for their evolving capacities. The child offender is considered an agentive child who must accept responsibility. Although the youth courts are required to have regard to the welfare of the child, ${ }^{28}$ welfare issues are not a primary or paramount consideration of the court. ${ }^{29}$

This simplistic, desensitising and pejorative portrayal of young people in trouble plays on popular fears about young offenders and provides a 'discursive benchmark' 30 which underpins and dominates the development of youth justice law and policy in a way which is unsympathetic to a discourse of rights, egalitarianism, inclusion and justice. What the current system of youth justice does insufficiently is to locate the behavioural repertoires of young people within a holistic socio-economic context. Arguably, this void constitutes a significant political, organisational and moral failure that could be rectified by

25 Crime and Disorder Act 1998, s 37.

26 Children and Young Persons Act 1933, s 44.

27 Benrhard Babic, 'Ohne intellektuelle Redlichkeit kein Fortschritt. Kritische Anmerkungen zum Umgang mit dem Capability Approach aus erziehungswissenschaftlicher Sicht' in Clemens Sedmak, Bernhard Babic, Reinhold Bauer and Christian Posch (eds), Der Capability-Approach in sozialwissenschaftlichen Kontexten (VS Verlag fur Sozialwissenschaften 2011) 82. Also Gunter Graf, Oscar Germes-Castro and Bernhard Babic, 'Approaching Capabilities with Children in Care: An International Project to Identify Values of Children and Young People in Care' in Ortrud Lebmann (ed), Closing the Capabilities Gap (Barbara Budrich 2011) 267.

28 Children and Young Persons Act 1933, s 44.

29 Crime and Disorder Act 1998, s 37; Raymond Arthur, 'Protecting the Best Interests of the Child: A Comparative Analysis of the Youth Justice Systems in Ireland, England and Scotland' (2010) 18(2) International Journal of Children's Rights 217.

30 Marcia K Meyers, Bonnie Glaser and Karin MacDonald, 'On the Front Lines of Welfare Delivery: Are Workers Implementing Policy Reforms?’ (1998) 17 Journal of Policy Analysis and Management 22. 
emphasising the importance of acknowledging children's evolving capacities in the maintenance of their rights. Such an approach would redirect the criminal justice system towards a normative framework better equipped to accommodate the realities of childhood. This framework would contain a clear foregrounding of the child's experiences and the reality of daily life and one in which the child's experience of vulnerability and powerlessness is embedded throughout. An approach based upon respect for children's rights is one which clearly resonates with Dixon and Nussbaum's capabilities (or human development) approach. ${ }^{31}$

\section{Evolving capacities}

Dixon and Nussbaum's capabilities approach is an emerging theory based on the idea of human dignity. According to Dixon and Nussbaum's capabilities approach, children come into the world with a variety of undeveloped capacities and there is a consequent moral need to protect them while these capacities develop. ${ }^{32}$ The capabilities approach aims at supporting the growth of agency and practical reasoning by urging a duty upon the state to help realise the capacity of each individual to think and reason in an informed and independent way. As such, children should be afforded the maximum scope for decisional freedom consistent with their actual capacity for rational and reasoned forms of choice or judgement. ${ }^{33}$ Dixon and Nussbaum argue that children have a right to assistance in reaching their capabilities, otherwise they will be 'mutilated and deformed' by their experiences. This right to assistance and protection is recognised in other parts of the English legal system. For instance, a young person must be 16 years old before they can consent to sexual relations, including consensual sexual relations with another young person. A young person cannot join the armed forces until they are 16 years old. They must be 18 years old to buy cigarettes or alcohol, get a tattoo or vote. There are exceptions to the rules of contract which apply to young people. ${ }^{34}$ Within family law, young people are assumed to lack the competency to participate responsibly and articulate their own wishes and feelings unless they can prove to the court that they have sufficient understanding. ${ }^{35}$ Thus, the law recognises that these actions require a certain level of maturity and capacity and that children need protection in a paternalistic form from the long-term consequences of their immaturity in various areas of their lives.

Dixon and Nussbaum argue that it is because of their human frailty, particularly so with children, that the 'state has an obligation to ensure that all persons have access to a life worthy of human dignity'. ${ }^{36}$ A particularly salient feature of the capabilities approach in the context of youth criminal liability is that it provides a normative framework for the evaluation of the development and well-being of individual persons, as well as for the assessment of the quality of social arrangements. ${ }^{37}$ Clark and Eisenhuth suggest that the 'same metric of human dignity applied to adults should also be addressed to children,

31 Rosalind Dixon and Martha Nussbaum, 'Children's Rights and a Capabilities Approach: The Question of Special Priority’ (2012) 97 Cornell Law Review 549.

32 Jean-Michel Bonvin and Daniel Stoeklin, 'Introduction' in Daniel Stoecklin and Jean-Michel Bonvin (eds), Children's Rights and The Capability Approach: Challenges and Prospects (Springer 2014) 10.

33 Ibid.

34 Sales of Goods Act 1979S, s 3(2).

35 F (Mother) v F (Father) [2013] EWHC 2683 (Fam); Gillick v West Norfolk \& Wisbech AHA [1986] AC 112; Mabon $v$ Mabon [2005] EWCA Civ 634; Re H [1993] 1 FLR 440.

36 Dixon and Nussbaum (n 31).

37 Hans-Uwe Otto, Albert Scherr and Holger Ziegler, 'On the Normative Foundation of Social Welfare: Capabilities as Yardstick for the Critical Social Work' in Hans-Uwe Otto and Holger Ziegler (eds), Enhancing Capabilities: The Role of Social Institutions (Barbara Budrich 2013) 197. 
even though it might need to be specified in a certain age-dependent way'. ${ }^{38}$ The capabilities approach implicitly advocates egalitarian, political conceptions of social justice which are concerned with the cultivation, maximisation and just distribution of the (real) freedom of individuals. ${ }^{39}$ The attention to what rights, goods, institutions or services do to human beings implies the necessity to focus on real tangible, dependent and vulnerable human beings with their own biographies, specific needs and socially and culturally embedded ways of conducting their lives. Therefore, the capabilities perspective commands a high degree of context sensitivity. ${ }^{40}$ From the capabilities perspective, it is the task of public institutions to ensure that individuals can in reasonable and tolerable conditions decide on their own in favour of the realisation of these capabilities. ${ }^{41}$ Beyond looking at the actual choices made by children, it is much more interesting to consider the fact that they may not have freedom to choose alternative ways of being and acting. ${ }^{42}$ Children and young people are still developing in terms of their cognitive capacity and emotional maturity and are often much more impulsive than adults. Children involved in crime, particularly persistently, are often the least ready to assume the responsibilities associated with autonomous individuality, to participate effectively in their own criminal proceedings, and the most seriously in need of adult help and guidance.

Other theorists have also developed paternalistic approaches which, similar to Dixon and Nussbaum, acknowledge the right of the child to recognition and protection of their vulnerability. In Feinberg's view, children cannot be adjudged as autonomous agents. ${ }^{43}$ Autonomy connotes the capacity for 'ethical evaluation and self-control', 44 as well as the competency for self-rule or self-government, which is based on personal rationale, deliberations, choices and motivations and, more importantly, freedom from external manipulations, distortions and coercions. ${ }^{45}$ Feinberg contends that children possess 'anticipatory autonomy rights' that draw their importance from the adult the child will become. Feinberg designated these rights as the child's right to 'an open future' because they exist to facilitate the child's development of autonomy. ${ }^{46}$ Feinberg's 'open future' principle has been widely invoked in applied ethical discourses such as genetic reproductive technologies, ${ }^{47}$ however, its relevance for application in the context of children involved in the criminal justice system cannot be underestimated as it acknowledges children's inherent vulnerability and immaturity and their lack of capacity and agency to make decisions in their own best interests. The right to an open future is a

38 Zoë Clark and Franziska Eisenhuth, 'The Capability Approach and Research on Children' in Sabine Andresen, Isabell Diehm, UweSander and Holger Ziegler (eds), Children and the Good Life: New Challenges for the Research on Children (Springer 2010) 72.

39 Zoë Clark and Holger Ziegler, 'The UN Children's Rights Convention and the Capabilities Approach: Family Duties and Children's Rights in Tension' in Bonvin and Stoecklin (n 32) 215.

40 Ibid 216.

41 Ibid 218.

42 Ibid 221.

43 Joel Feinberg, 'The Child's Right to an Open Future' in William Aiken and Hugh LaFollette (eds), Whose Child? (Rowman \& Littlefield 1980) 124; Joel Feinberg, The Moral Limits of the Criminal Law: Harm to Self (OUP 1986) 325-26.

44 Andrew Franklin-Hall, 'On Becoming an Adult: Autonomy and the Moral Relevance of Life's Stages' (2013) 63 Philosophical Quarterly 223, 251.

45 Immanuel Kant, 'Grounding for the Metaphysics of Morals' in Ethical Philosophy, James W Ellington (trans) (Hackett Publishing 1785/1983).

46 Oduntan Jawoniyi, 'Religious Education, Critical Thinking, Rational Autonomy, and the Child's Right to an Open Future' (2015) 42 Religion and Education 34.

47 For example, see Dena S Davis, Genetic Dilemmas: Reproductive Technologies, Parental Choices and Children's Futures (Routledge 2000). 
right to have future options available until the child is 'a fully formed self-determining adult' capable of making their own choices. ${ }^{48}$ This right protects the child against having important life choices determined by others before she has the ability to make them for herself so as to preserve the child's future options. It therefore includes restrictions on what others are allowed to do to children as it is imperative that the child's future options are not prematurely closed. ${ }^{49}$

Hollingsworth has suggested that a system of criminal justice will be illegitimate if it permanently restricts the child's ability to develop the capacities necessary for future global autonomy. ${ }^{50}$ To ensure that children can develop into fully autonomous rightsholders when they achieve majority, the state must give special status to a particular category of childhood rights that Hollingsworth characterises as 'foundational rights', which support the child in becoming autonomous at the point of achieving majority. This 'foundational rights' approach requires that children are treated according to principles of equality, due process and justice, but any punishment cannot permanently restrict the child's ability to develop the capacities necessary for future global autonomy. Specifically, in this context it requires the age of criminal responsibility to be set above the age at which punishment would cause irreparable harm to the child's foundational rights.

Tobin's rights-based construction of childhood develops Feinberg's 'open future' principles and Hollingsworth's 'foundational rights' approach further by arguing that the best interests of the child are, as a minimum, a primary consideration in all matters concerning them. ${ }^{51}$ Tobin argues that a rights-based approach provides conceptual clarity when determining the meaning and content of the child's best interests. The indeterminacy of the child's best interests has often allowed it to be used as a proxy for the interests of others. ${ }^{52}$ Ultimately, Tobin posits that a rights-based approach demands that a child's best interests be informed by a consideration of all of the other rights of the child. ${ }^{53}$ Tobin recommends that courts adopt an evidence-based approach when determining the best interests of the child by using empirical evidence in relation to the specific child, or children more generally. The law's assumptions about children's criminal capacity are unsupported by the bulk of empirical research concerning the mental capabilities of preadolescents. Developments in neuro-imaging technology have allowed for a more detailed understanding of the adolescent brain which has found that there are developmental differences in the brain's biochemistry and anatomy that may limit adolescents' ability to perceive risks, control impulses, understand consequences and control emotions. ${ }^{54}$ The prefrontal lobe is involved in behavioural facets germane to

48 Mianna Lotz, 'Feinberg, Mills, and the Child's Right to an Open Future' (2006) 37(4) Journal of Social Philosophy 537, 539.

49 Claudia Mills, 'The Child's Right to an Open Future' (2003) 34(4) Journal of Social Philosophy 499; Joseph Millum, 'The Foundation of the Child's Right to an Open Future' (2014) 45(4) Journal of Social Philosophy 522.

50 Kathryn Hollingsworth, 'Theorising Children's Rights in the Youth Justice System: The Significance of Autonomy and Foundational Rights’ (2013) 76(6) Modern Law Review 1049.

51 John W Tobin, 'Courts and the Construction of Childhood: A New Way of Thinking' in Michael D Freeman (ed), Law and Childhood Studies: Current Legal Issues (OUP 2012) 55.

52 Robert van Krieken, 'The Bests Interests of the Child and Parental Separation' (2005) 68(1) Modern Law Review 25, 39.

53 John W Tobin, 'Taking Children's Rights Seriously: The Need for a Multilingual Approach' in Alison Diduck, Noam Peleg and Helen Reece (eds), Law in Society: Reflections on Children, Family Culture and Philosophy (Brill 2015) 127-40, 134.

54 Frances J Lexcen, Dickon N Reppucci, 'Effects of Psychopathology on Adolescent Medical Decision-Making' (1998) 5(63) University of Chicago Law School Roundtable 63, 77; Sara B Johnson, May Sudhinaraset, Robert W Blum, 'Neuromaturation and Adolescent Risk Taking: Why Development is Not Determinism' (2010) 25(1) Journal of Adolescent Research 4, 10. 
many aspects of criminal culpability' including 'the control of aggression and other impulses 55 and yet this lobe is the last area to mature. ${ }^{56}$ This research has examined the brain development and cognitive functioning of adolescents and has found that, with respect to moral culpability, those parts of the brain that deal with judgement, impulsive behaviour and foresight develop in the twenties rather than the teen years. ${ }^{57}$ Because the prefrontal lobe is not fully mature and is still developing during adolescence, teens are almost inevitably overly emotional, more prone to risk-taking and subject to wide mood swings, immature judgement, decreased risk perception and impaired future-time perspective. ${ }^{58}$ Furthermore, their functioning in respect of considering issues empathically from the perspective of others, capacity for autonomy and resisting pressure from others and their ability to experience guilt and shame are under-developed. ${ }^{59}$ This contributes to the tendency to make choices that are harmful to themselves and others.

Additionally, the way in which psycho-social factors influence decision-making and the kinds of choices adolescents make depend in part on the social and family context in which young people find themselves. Children involved in crime, particularly where that involvement is persistent, have often had difficult, deprived backgrounds and serious multiple problems in terms of their school achievement, psychological health, alcohol and drug abuse and family life. ${ }^{60}$ The challenges that confront children who are engaging in anti-social and offending behaviour, their families and the various professionals who work with them are complex, deep-rooted and multi-faceted. These children are the most disadvantaged, have the poorest educational experiences and are more likely to suffer from poor health, including mental health and substance misuse.

These developmental differences render such children and young people the least ready to assume the responsibilities associated with autonomous individuality and to participate effectively in their own criminal legal proceedings, and the most seriously in need of adult help and guidance. Evidence suggests that young defendants often do not understand legal proceedings or the language used by lawyers, they report feeling intimidated and isolated in court and may not receive a proper explanation of what has happened until after a hearing is over. ${ }^{61}$ Children lack the ability to concentrate for long periods and it may be difficult for them to participate properly in proceedings. The child may not be able to follow evidence and may not understand the complex language used in court. As a result he may not be able to give instructions to his lawyer and may not be in a position to make vital decisions. ${ }^{62}$ Young offenders also feel frustration that the

55 Ruben C Gur, 'Brain Maturation and the Execution of Juveniles' (2005) University of Pennsylvania Gazette 103.

56 Peter Kelly, 'The Brain in the Jar: A Critique of Discourses of Adolescent Brain Development' (2012) 15(7) Journal of Youth Studies 944, 946.

57 William Di Mascio, 'Punishment Has Replaced Juvenile Redemption' (2006) Correctional Forum 2; Gur (n 55).

58 Kathryn L Modecki, 'Addressing Gaps in the Maturity and Judgment Literature: Age Differences and Delinquency' (2008) 32 Law and Human Behaviour 78; Jane Rutherford, 'Juvenile Justice Caught between The Exorcist and A Clockwork Orange' (2002) 51 De Paul Law Review 715, 727.

59 Nigel Stone, 'Old Heads upon Young Shoulders: “Compassion to Human Infirmity” Following R v JTB' [2010] 32(3) Journal of Social Welfare and Family Law 287, 292.

60 Raymond Arthur, Family Life and Youth Offending: Home is Where the Hurt Is (Routledge 2007).

61 Neal Hazel, Ann Hagell and Laura Brazier, Young Offenders' Perceptions of their Experiences in the Criminal Justice System (Policy Research Bureau 2002); Michelle Botley, Becca Jinks and Carol Metson, Young People's Views and Experiences of the Youth Justice System (Children's Workforce Development Council 2010); Ali Wigzel, Amy Kirby and Jessica Jacobson, The Youth Proceedings Advocacy Review: Final Report (Bar Standards Board 2015).

62 Thomas Croft, The Criminal Responsibility of Children and Young Persons (Ashgate 2002) 78. 
courts seem rarely to understand the context in which their offences were committed, including the pressures facing them.

Schapiro characterises childhood as a 'non-ideal status of normative immaturity'. Schapiro suggests that the progression from childhood to adulthood is a progression from heteronomy to self-hegemony. ${ }^{63}$ According to Schapiro, 'autonomy starts out as sovereignty over limited domains of discretion'. The development of children's autonomy will be aided by allowing them to develop their self-hegemony in a piecemeal fashion, such that they gradually achieve self-determination over the various 'domains of their lives'. ${ }^{64}$ For Schapiro, this imposes an obligation on the part of parents and the state to strive to reduce their child's predicament of subjection to the will of others, so as to enable them to 'awaken to a sense of their own freedom and responsibility' and become 'free to control themselves'. ${ }^{65}$ It is in this way that children become able to govern themselves as free wills. ${ }^{66}$ For Schapiro, recognition that children occupy a 'non-ideal status of normative immaturity' imposes obligations on parents and society to do what is in our power as adults to help children work their way out of childhood. Our negative obligation as adults must be to refrain from hindering them in this effort. ${ }^{67}$

\section{UN law and European law}

The current law on the age of criminal responsibility takes no account of the child's inexperience and evolving capacities and powers of self-control and reasoning, which make them prone to acting in ways they cannot help, understand or intend. In international human rights law, the child's 'anticipatory autonomy rights' are explicitly linked to the concept of the child's evolving capacities in the UN Convention on the Rights of the Child (UNCRC) which represents the most comprehensive legally binding statement of children's rights. The UNCRC embraces the concept of autonomy where it is inextricably linked to the concept of the child's evolving capacities, ${ }^{68}$ the principle of the child's active and informed participation in all matters affecting her or him ${ }^{69}$ and the understanding that children are independent holders of rights. ${ }^{70}$ The evolving capacities principle of the UNCRC is codified in Article 5 which states that:

States parties shall respect the responsibilities, rights and duties of parents or, where applicable the members of the extended family or community as provided for by local custom . . . to provide in a manner consistent with the evolving capacities of the child, appropriate direction and guidance in the exercise by the child of the rights recognized in the present Convention.

The notion of the child's evolving capacities is also reflected in Article 12.1 which reads as follows:

States Parties shall assure to the child who is capable of forming his or her own views the right to express those views freely in all matters affecting the child, the

63 Tamar Schapiro, 'What Is a Child?' (1999) 109 Ethics 715.

64 Mianna Lotz, 'Feinberg, Mills, and the Child's Right to an Open Future' (2006) 37(4) Journal of Social Philosophy 537, 539.

65 Schapiro (n 63).

66 Christine M, Korsgaard, Creating the Kingdom of Ends (CUP 1996) 159.

67 Schapiro (n 63).

68 Article 5, UNCRC.

69 Ibid Article 12.

70 Manfred Liebel, 'From Evolving Capacities to Evolving Capabilities: Contextualizing Children's Rights' in Bonvin and Stoecklin (n 32) 67. 
views of the child being given due weight in accordance with the age and maturity of the child.

Furthermore, the preamble of the UNCRC refers to the notion of dignity:

Considering that, in accordance with the principles proclaimed in the Charter of the United Nations, recognition of the inherent dignity and of the equal and inalienable rights of all members of the human family is the foundation of freedom, justice and peace in the world. ${ }^{71}$

This echoes the Universal Declaration of Human Rights which states that: 'All human beings are born free and equal in dignity and rights. ${ }^{, 72}$ The evolving capacities principle can thus be understood as a stimulant for the recognition of the special capacities of children and their promotion, taking into account that children are in a process of development, but not necessarily ranking these capacities in a hierarchical sense.

The UNCRC promotes the view that children are no longer merely 'potential adults' but are cast as full human beings invested with important social citizenship rights, ${ }^{73}$ including the right to have their best interests seen as a primary consideration in all court actions involving them (Article 3). The primary importance of Article 3 is in making children's interests visible and giving them force in decision-making processes. ${ }^{74}$ The UNCRC not only constructs children as rights-bearing citizens with a range of social, political and civil rights, but also calls upon states to ensure that they are active, participating citizens, playing a role in governance 'according to their age and maturity', rather than simply 'being passively governed'. ${ }^{75}$ The UNCRC recognises that young people under the age of 18 years may need special protection because of their age or emotional development. Consequently, in the context of the age of criminal responsibility, Article 40 of the UNCRC requires each state to set a reasonable minimum age of criminal responsibility. The UN Standard Minimum Rules for the Administration of Juvenile Justice (the Beijing Rules) 1985 recommend that this minimum age shall not be fixed at too low an age level, bearing in mind the facts of emotional, mental and intellectual maturity. The important consideration, as outlined in rule 17 of the Beijing Rules, is whether a child, by virtue of his or her individual discernment and understanding, can be held responsible for their behaviour. The Commentary to the Beijing Rules stresses that there should be a close relationship between the age of criminal responsibility and the age at which young people acquire other social rights such as marital status and the right to vote. In line with this rule, the UN Committee on the Rights of the Child has recommended the age of 12 years as the absolute minimum age of criminal responsibility. ${ }^{76}$

In $R v G^{77}$ Lord Steyn believed that the UNCRC created a norm which acknowledged that the criminal justice system should take account of a defendant's age, level of maturity, and intellectual and emotional capacity. Lord Steyn emphasised that ignoring the

71 Preamble, UNCRC.

72 Article 1, Universal Declaration of Human Rights.

73 Raymond Arthur, 'Recognising Children's Citizenship in the Youth Justice System' (2015) 37(1) Journal of Social Welfare and Family Law 21.

74 Rachel Taylor, 'Putting Children First? Children's Interests as a Primary Consideration in Public Law' (2016) 28(1) Child and Family Law Quarterly 45.

75 Daiva Stasiulis, 'The Active Child Citizen: Lessons from Canadian Policy and the Children's Movement' (2002) 6(4) Citizenship Studies 507, 509.

76 UN Committee on the Rights of the Child, General Comment No 10: Children's Rights in Juvenile Justice (UN Committee on the Rights of the Child 2007) 32.

77 [2003] UKHL 50, [2004] 1 AC 1034. 
special position of children in the criminal justice system is not acceptable in a modern civil society. In the same case, Lord Bingham held that it was neither moral nor just to convict a young person on the strength of what someone else would have apprehended if the defendant himself had no such apprehension. As Lord Diplock stated, in the differing context of the former partial defence of provocation to murder, 'to require old heads on young shoulders is inconsistent with the law's compassion of human infirmity. ${ }^{78}$ More recently, the Court of Appeal stated in $R v L$, in the context of young defendants trafficked into the UK who had been convicted of various offences including the production and supply of cannabis and use of a forged passport, that age is always a relevant factor in the case of a child defendant which may significantly diminish, and in some cases effectively extinguish, their culpability. ${ }^{79}$

The EU Commission's 2006 communication, Towards an EU Strategy on the Rights of the Child, adopts the UNCRC as the established benchmark for children's rights at EU level. ${ }^{80}$ The 2011 EU Agenda for the Rights of the Child reinforces the full commitment of the EU to promote, protect and fulfil the rights of the child in all relevant EU policies and actions. The 2011 Agenda includes 11 concrete actions where the EU can contribute in an effective way to children's well-being and safety; these actions include the development of a 'child-friendly' justice system. The European Committee of Social Rights has also declared that the age of criminal responsibility in England is 'manifestly too low' and accordingly is not in conformity with Article 17 of the European Social Charter which provides mothers and children with a right to social and economic protection. ${ }^{81}$ The European Social Charter, a Council of Europe treaty signed in 1961, guarantees social and economic human rights. The Council of Europe's Human Rights Commissioner has also frequently expressed concern at the low age of criminal responsibility in England. The Commissioner in 2005, Alvarez Gil-Robles, commented that he had 'extreme difficulty in accepting that a child of 12 or 13 can be criminally culpable for his actions, in the same sense as an adult'. ${ }^{82}$ While noting that the European Convention on Human Rights (ECHR) does not require any age limit to be set before a child can be held criminally responsible, the Commissioner suggested that the age level in England should be raised to bring it into line with other European countries. In 2009 the Commissioner Thomas Hammarberg argued for an increase in the age of criminal responsibility across Europe with the aim of progressively reaching 18 years and recommended that innovative systems of responding to juvenile offenders below that age should be tried with a genuine focus on their education, reintegration and rehabilitation. ${ }^{83}$ In $V$ and $T v U K^{84}$ the European Court of Human Rights recognised the variation in minimum ages across Europe and, though stating that the age of 10 years in England is at the lower end of the spectrum, held that 'it cannot be said to be so young as to differ disproportionately from the age limit followed in other European States'. ${ }^{85}$ Nevertheless, the principle of acknowledging the evolving capacities of young people was recognised by the European

78 Camplin [1978] AC 705, 717.

79 [2013] EWCA Crim 991, para 13.

80 EU Commission, Towards an EU Strategy on the Rights of the Child (COM367 2006).

81 European Committee of Social Rights, Conclusions XVII-2 (UK) Articles 7, 8, 11, 14, 17 and 18 of the Charter (Council of Europe 2005) [30].

82 Alvarez Gil-Robles, Report on bis Visit to the UK 4th-12th November 2004 for the Attention of the Committee of Ministers and the Parliamentary Assembly (Council of Europe 2005) [105].

83 Thomas Hammarberg, The Human Rights Dimension of Juvenile Justice (CommDH/Issue Paper Council of Europe 2009).

84 (2000) 3 EHRR 121.

85 Ibid [74]. 
Court of Human Rights in $V$ and $T v U K$. In this case Lord Reed held that: 'Even children who may appear to be lacking in innocence or vulnerability are nevertheless evolving, psychologically as well as physically, towards the maturity of adulthood.' 86 This case involved Jon Venables and Robert Thompson, two boys convicted of murdering toddler James Bulger in 1993. The European Court of Human Rights was particularly struck by the paradox that children who were deemed to have sufficient mental capacity to engage their criminal responsibility had a play-area made available to them during adjournments. Indeed, five dissenting judges expressed the view that fixing 10 as the age of criminal responsibility was almost certainly in breach of Article 3 ECHR.

\section{Conclusion}

What is evident is that the youth justice system in England and Wales uses an adult template to measure young people's criminal responsibility and overlooks young people's particular vulnerabilities. Acknowledging that the child has a right to respect for their evolving capacities does not seek to impose controls on children but to provide boundaries which are not fixed and are typically renegotiated by children. ${ }^{87}$ Applying such a children's rights approach to young people in conflict with the law would ensure that young people who are not sufficiently mature and competent to understand the process of a trial in a criminal court, including the youth court, could not be held criminally culpable for their behaviour. Criminal liability could only be imposed after an assessment of the mental capacity, competence and maturity of each child. Such an assessment would need to acknowledge the limitations of criminal justice as a means of preventing and dealing with crime and antisocial behaviour and instead consider whether the child's needs would best be met by non-criminal methods of social intervention.

The method being advocated here is not without criticism as it may lead to unclear and unpredictable outcomes. Emphasising such an individualised focus on the child's needs may plausibly result in uncertain and unclear outcomes and disproportionate and indeterminate treatments, in circumstances where if an adult had committed the offences they would have been treated more leniently. Certainty has traditionally been seen as an important and defining characteristic of the rule of law. ${ }^{88}$ For example, Hayek stressed that the rule of law should involve rules rather than standards, determinate rather than open-ended language and closure rather than continued deliberation. ${ }^{89}$ What is being proposed here undermines the certainty that is emphasised as part of the rule of law ideal. However, Eekelaar asks whether it should always be an object of legal processes to provide clear and predictable outcomes. ${ }^{90}$ Instead, he argued that the law provides points of departure and frameworks within which reasoned decisions are taken, but 'thoughtful discretion' is also included rather than the law operating in a mechanical and thoughtless way in the pursuit of an exalted ideal of predictability. Waldron has described the processes by which such decisions are taken within legal systems as 'forms of argumentative thoughtfulness' 91 which he considers to be a key feature of the rule of law.

86 Ibid.

87 Jerome Ballet, Mario Biggeri and Flavio Comim, 'Children's Agency and the Capability Approach: A Conceptual Framework' in Mario Biggeri, Jerome Ballet and Flavio Comim (eds), Children and the Capability Approach (Palgrave 2011) 30.

88 Friedrich von Hayek, The Road to Serfdom (University of Chicago Press 1944); Friedrich von Hayek, The Constitution of Liberty (University of Chicago Press 1960).

89 Ibid.

90 John Eekelaar, 'The Role of the Best Interests Principle in Decisions Affecting Children and Decisions about Children' (2015) 23(3) International Journal of Children's Rights 3, 25.

91 Jeremy Waldron, 'Thoughtfulness and the Rule of Law' (2011) 18 British Academy Review 4. 
This altruistic paternalism is justified as the temporal position of childhood and adolescence in the ordinary lifespan justifies holding children to different standards when determining their ability to make choices. ${ }^{92}$ This is not to imply that the harms caused by youth-offending should be tolerated, but means ensuring that all children who are alleged to have offended have access to the range of health and social care services they require whether they are formally prosecuted or not. This view of young people recognises that the child offender lacks capacity and, consequently, there is a need for both the family and the state to take responsibility for children's needs and to respond to youth-offending by providing young people with the necessary tools to grow into civilised and competent adults. This is underpinned by the pursuit of social justice and a prevailing assumption that the role of the state is to try to realise a more just, equitable and inclusive society.

The low age of criminal responsibility underestimates the relevance of age and the full trajectory of development from childhood through adolescence and to adulthood. It ensures that the power imbalance between children and adults is sustained, the special status of childhood is diminished and the child's human rights are violated. The low age of criminal responsibility marginalises the important developmental differences between children and adults and allows the criminal justice system to treat young offenders as entirely rational, fully responsible young adults rather than children, thus justifying their subjection to the full rigours of the criminal law. As Lord Dholakia stated when introducing the Age of Criminal Responsibility Bill in the House of Lords, 'children who are too young to attend secondary school can be prosecuted and receive a criminal record'. ${ }^{93}$ Raising the age of criminal responsibility would bring conceptual attention to the nature of the child's evolving capacities and would stimulate an integrated analysis of how to respond to youthful antisocial and offending behaviour by considering how multiple stakeholders such as families, schools, social workers and government can affect children's well-being. Such an approach opens the way for evaluating the effect of criminal justice responses on particular children and for creative solutions to be developed. As Lord Dholakia stated:

It cannot be right to deal with such young children in a criminal process based on ideas of culpability which assume a capacity for mature, adult-like decisionmaking. There is no other area of law - whether it is the age for buying a pet, the age for paid employment, the age of consent to sexual activity or the age for smoking and drinking - where we regard children as fully competent to take informed decisions until later in adolescence. The age of criminal responsibility is an anomalous exception. ${ }^{94}$

92 Andrew Franklin-Hall, 'On Becoming an Adult: Autonomy and the Moral Relevance of Life's Stages' (2013) 63 Philosophical Quarterly 223.

93 HL Deb 8 November 2013, vol 749, cols 476, 479.

94 HL Deb 8 November 2013, vol 749, col 477. 